\title{
Towards exploring expertise in mathematics education research: What are the requirements and duties of the researchers?
}

\author{
Igor' Kontorovich $^{1^{*}}$ and Orit Hazzan ${ }^{1}$ \\ ${ }^{1}$ Department of Education in Technology and Science, Technion - Israel Institute of Technology, Haifa, Israel \\ *ik@tx.technion.ac.il
}

\begin{abstract}
While considerable resources are invested in mathematics educational research and in nurturing future scholars, little is known about expertise in this field. In this paper, we explore the requirements and duties of mathematics educational researchers, as a preliminary step towards characterizing the components of their expertise. The data corpus of the study consisted of 57 position announcements for assistant and associate professor in 48 universities and 4 colleges located in thirty US states. An inductive content analysis revealed four types of requirements and duties: (1) required background in mathematics and mathematics education; (2) teaching and mentoring duties; (3) research and publishing obligations; (4) department and university duties. The implications of the findings are discussed from the perspectives of high-education programs and graduate students who are considering mathematics education research as their career track. The findings are used to formulate goals and questions for further studies.
\end{abstract}

Keywords: Expertise, high-education, mathematics educational community, researchers.

\section{Introduction}

The role of scientific research cannot be underestimated in the modern world, since it manifests in every aspect of our lives: Research promotes our knowledge in different subjects, its findings are used by policymakers, and its applications are widely used even by people who are not experts in the field (Gordon \& Porter, 2009). Countries are commonly compared according to their research funds, their research institutions, and their publication ratings in prestigious research journals (e.g., Man, Weinkauf, Tsang, \& Sin, 2004; Pavan, 2013). Moreover, for of practitioner-scientists and undergraduate and graduate, students worldwide, academic research is a career choice. In light of the above, exploring the phenomenon of expertise in scientific research is highly relevant both for the research community striving to improve its own practices, and for all others who will eventually benefit from this improvement.

In education, and in mathematics education in particular, the cohort of research experts (i.e. experienced and acknowledged academic scholars) is very influential in a number of ways: Their research contributes to the body of knowledge of mathematics education and shapes the field's state of the art, experts counsel policy-makers, design learning programs and materials, train prospective teachers, and support in-service teachers; experts also mentor graduate students, some of which will go on to become leading scholars in mathematics education research. In light of the above, exploring experts' ways of thinking and their practices can benefit the mathematics education community and contribute to the communication and cooperation among its members. Moreover, exploring the characteristics of expert mathematics education researchers (MERchers) can be seen as a natural evolvement on the part of the mathematics education community, which was initially interested in students and teachers (e.g., Safford, 1893; Hanus, 1897) and over the years embraced also mathematicians, teacher educators, parents, policymakers and others due to their significance to the learning and teaching enterprise (e.g., Ma, 2001; Riley \& Torrance, 2003; Weber, 2008; Zaslavsky \& Leikin, 2004). 


\section{Literature Review}

Overall, the literature on expertise in scientific research can be divided into two categories: selfreflective publications of practicing scientists (e.g., ICTP, 2004) and studies on research development of undergraduate and graduate students (e.g., Spronken-Smith, Mirosa \& Darrou, 2013). In the first category, scientists offer overviews of their journeys to becoming researchers, elaborating on the challenges of combining an academic life with an every-day one, and providing practical suggestions for research students and novice researchers on choosing good scientific problems, building motivated and efficient research groups, getting research published, mentoring graduate students and so on (Alon, 2009, 2010; Chamovitz, 2010; Chen \& Anderson, 2008; Clarke, 2004; Day, 1996; Delamont, Atkinson \& Parry (2004); Sneider \& Larner, 2009; Strnadova, Cumming, Knox \& Parmenter, 2013; Townsend, 2004).

Despite the richness of the reflective literature, two observations should be made: First, research on expertise repeatedly shows that experts excel in their core practices and not necessary in the analysis of these practices (see elaborated discussion on this issue in Van Someren, Barnard \& Sandberg, 1994). Second, in their publications, scientists barely refer to their scientific subjects, a situation that gives the impression that the suggested insights are relevant for all research fields. This assumption deserves meticulous investigation, since research in natural sciences (from which the majority of the reflecting scientists come from) is fundamentally different from research in social sciences. Moreover, the singularity of research in mathematics education (see Introduction) puts it in a special position within the inclusive and diverse family of social sciences.

The second category of literature addresses undergraduate and graduate students' perceptions, knowledge and skills relating to scientific research (e.g., Haser \& Çakiroğlu, 2012). Although many papers mention the research field of the students (e.g., see Abu-Zaid \& Alkattan, 2013 for medicine; Nurius \& Kemp, 2013 for social work; Sales, 2013 for law; Ullrich, Dumanis, Evans, Jeannotte, Gale, Wolfe, \& Forcelli, accepted for neuroscience; and Ward, 2013 for electrical and information engineering), in most cases education students are still treated as one cohort with no differentiation between subject matters (e.g., see Grammatikopoulos, Gregoriadis, \& Zachopoulou, 2013 and Spronken-Smith, Mirosa, \& Darrou, 2013 to support this claim, and Haser \& Çakiroğlu, 2012 for an exceptional case of mathematics education doctoral students).

In light of the above, it can be concluded that the shortcomings of the existing literature on expertise in scientific research presented above warrant a rigorous empirical investigation of expertise in mathematics educational research.

\section{The study}

Research on experts and their practices repeatedly show that expertise is a complex multi-faceted human endeavor (e.g., Carlson \& Bloom, 2005; Newell \& Simon, 1972; Schoenfeld, 1992). Taking into consideration the available literature that can serve as a theoretical background for the study (see Literature Review), it seems that there is merit in taking empirical steps towards presenting an overview of the components of expertise in mathematics educational research. The current study is our first step in this direction and its goal is to explore job descriptions of MERchers. Hence, the research question of the study is: What are the requirements and duties of MERchers?.

The data base for this study consisted of 57 position announcements in the field of mathematics education published by 48 universities and 4 research colleges located in thirty US states. The announcements were collected from Jerry Becker's mailing list between the end of August 2013 and the end of March 2014. The announcements refer to positions that will be opening in September 2014. Jerry Becker's mailing list is frequently used to disseminate information that is relevant to the mathematics educational community, such as publications of new articles and books, calls for papers in research journals, invitations to international conferences, and position announcements. 
All of the announcements studied referred to positions of assistant professor and associate professor, which, according to USA academic ranks, are the starting positions in the academic hierarchy. A PhD degree was revealed to be a necessary requirement for each of the positions. Thus, the chosen design of the study has potential to add insights about the expertise of people who have already proved their professionalism and engagement in mathematics education research.

The data were analyzed using an inductive content analysis approach, which was deemed suitable for our goal and research question. Indeed, Elo and Kyngas (2008) wrote that "The aim [of content analysis] is to attain condensed and broad description of the phenomenon, and the outcome of the analysis is concepts or categories describing the phenomenon" (p. 108). Following the principle whereby "[...] many words of the text are classified into much smaller content categories" (Elo \& Kyngas, 2007 based on Weber, 1990 and Burnard, 1996), we began with a circular reading of the most elaborated announcements and used open coding to summarize and make sense of the contents. As a result of an iterative process of reorganization, the coded data were clustered in thematic sections and subsections that turned into an initial organizing framework. The framework was applied to the rest of the data and readjusted until an organizing framework emerged that was applicable for the entire data corpus. Eventually, a profile was generated for each announcement according to this framework (see Figure 1). The presented framework addresses into account only the differences between the announcements; These differences, as well as the similarities found, are presented in the Findings section.

\section{Position description}

Name of academic facility:

State:

University / College

Position of assistant / associate prof.

Background of sought candidate

A PhD in:

Required mathematical background:

Required teaching experience:

\section{Position duties}

Teaching

An accepted candidate is expected to teach academic courses in

which will aim to

\section{$\underline{\text { Research }}$}

Research interests of the candidates should include:

An accepted candidate is expected to collaborate with:

\section{Department and university duties}

Department and university duties of the accepted candidate will include:

Figure 1. Announcement profile 


\section{Findings}

All position announcements referred to four central themes: a background in mathematics and mathematics education as a requirement for the position, teaching and mentoring duties, research and publishing obligations, and department and university duties (service).

Required background in mathematics and mathematics education. All of the positions required a $\mathrm{PhD}$ degree, to be completed before the position start day. Only ten announcements exclusively addressed doctoral graduates in mathematics education; the other were all inclusive to 'related fields with a strong commitment to mathematics education'. Seven announcements exemplified these 'related fields', mentioning general education, statistical education, STEM (science, technology, engineering and mathematics) education, and mathematics sciences. Only three announcements explicitly referred to the proficiency and literacy of potential candidates in mathematics education. For instance, one of the announcements stated: "[...A]pplicants should demonstrate an understanding of the current landscape of mathematics education, including standards and key challenges." Only two announcements explicitly required the applicants to possess a methodological knowledge in qualitative and quantitative research. Presumably, in the rest of the cases, these competences were perceived as default. Indeed, all of the announcements requested candidates to send examples of their publications in mathematics education that may serve as evidence of the aforementioned required competences.

Only twenty eight announcements mentioned specific specialization areas in mathematics education as required areas of interest of potential candidates: elementary mathematics education $(n=12)$, secondary mathematics education $(n=9)$, teacher education $(n=7)$, relations between mathematics and science education $(n=11)$, bilingual education $(n=3)$, technology in teaching and learning ( $n=2$ ). Ten of these announcements stated that the particular specialization areas are prerequisites for applying for the position. In the remaining cases, the research interests specified were tagged as 'preferred'.

In terms of the mathematics background required of the sought candidates, the announcement requirements covered quite a broad spectrum: 31 positions required proven experience in teaching scholastic mathematics, 17 positions addressed people with experience teaching undergraduate mathematics courses, and 9 positions explicitly required a master's or even $\mathrm{PhD}$ degree in mathematics. Notably, a mathematical background was associated with academic courses that the accepted candidate was expected to teach.

Teaching and mentoring duties. One announcement required applicant to possess a teaching certificate, but just like the others, the relevant institution was willing to consider candidates with teaching experience but no teaching certificate. Eleven announcements specified at least 2 or 3 years of schoolteaching experience as a prerequisite applying for the position; in 18 cases, teaching experience was tagged as a 'preferred quality'. A recommendation letter, referring explicitly to the candidate's teaching competences, was required in twelve cases and considered as evidence of the candidate's teaching excellence. Experience with cultural diversity, multilingual education, and distant education technologies were defined as 'advantageous' for eight positions.

All of the announcements expected the accepted candidates to recruit and mentor graduate and research students. Twenty six announcements also included 'advising undergraduates and supervising student teachers' as a part of the offered position. In terms of teaching duties, the announcements differentiated between courses according to subject matter (mathematics, mathematics education, general education, and methodology) and the intended audience (undergraduates and graduates in mathematics education, students from other faculties, in-service teachers participating in developmental programs, graduates studying towards a teaching certificate), as presented in Tables 1 and 2. 
Table 1. Teaching duties by subject matter

\begin{tabular}{lc}
\hline Subject matters & $\begin{array}{c}\text { Number of positions } \\
\text { (out of 57) }\end{array}$ \\
\hline Mathematics & 17 \\
Mathematics education & 46 \\
General education & 3 \\
Methodology & 11 \\
\hline
\end{tabular}

Table 2. Teaching duties by intended audience

\begin{tabular}{lc}
\hline Intended audience & $\begin{array}{c}\text { Number of } \\
\text { announcements (out of 57) }\end{array}$ \\
\hline Undergraduates in math education & 57 \\
Graduates in math education & 57 \\
Students seeking teaching certificate & 9 \\
In-service teachers & 28 \\
\hline
\end{tabular}

Researching and publishing duties. All of the announcements explicitly referred to the candidates' ability to publish in high-ranking journals, present at conferences, and pursue external funding. Moreover, twenty seven announcements state that already possessing a research grant gives a candidate 'a significant advantage when applying for the position.

All of the announcements expected accepted candidates to become involved in research collaborations. Seven of them, referred to the STEM community and twenty two referred to colleagues from other departments (such as mathematics department) and academic facilities. In forty five cases the accepted candidates were expected to provide consulting services to private, local, state and national educational facilities and decision-makers. One announcement said that these services "Contribute to the national visibility, stature, and impact of the [...] mathematics education program [of the department]".

Department and university duties. In addition to the aforementioned requirements and duties, MERchers are expected to take an active part in department and university life. Namely, a researcher should contribute to the existing department programs, develop curricula for new programs, and participate in the accreditation process $(n=24)$, take part in committee work including master's, doctoral and other department committees $(n=35)$, participate in university outreach programs $(n=13)$, serve in leadership positions in professional organizations $(n=2)$, assist in developing highly effective teaching assistants, work to improve the undergraduate design sequence of mathematics courses, and implement and sustain professional school websites ( $n=1$ each).

\section{Summary and Implications}

The study presented in this paper was motivated by the importance of exploring expertise in mathematics education research and is perceived as a preliminary step in this direction. Fifty seven announcements for positions of assistant professor and associate professor in US universities and colleges were analyzed for primary requirements and duties of MERchers. The requirements and duties identified are: background in mathematics and mathematics education, teaching and mentoring duties, research and publishing obligations, and department and university duties. Experienced scholars may perceive these findings as being rather trivial, since experts are familiar with their own professional responsibilities. However, Haser and Çakiroğlu (2012) revealed that doctoral students in 
mathematics education may perceive the findings of the study differently: In an analysis of a workshop dedicated to academic careers, Haser and Çakiroğlu found that doctoral students refer only to the research and publishing component of the MERcher's job. Interestingly, the students failed to mention teaching and mentoring, although they themselves are the main consumers of these services supplied by professional MERchers.

The position announcements that served as data sources in our study referred to MERcher positions opening in September 2014 in thirty states in the US. Thus, it may be said that the requirements and duties identified in the study highlight components of expertise most frequently required nowadays in mathematics educational research in the US. Two limitations of the study, however, should be stressed: First, the four central themes identified in all of the position announcements seem rather broad and do not fully capture the essence of expertise in mathematics education research. Second, it is possible that one position announcement served as a prototype for another, and consequently, the findings do not reveal the true lay of the land. Therefore, we perceive the conducted study as a trigger for further empirical studies aimed at dissecting expertise in mathematics educational research. Presumably, these studies will be able to lean on our findings and use them as overarching structures that play a significant role in the job of a MERcher.

The more practical applications of the findings are now discussed from the perspective of higheducation programs and graduate students who are considering mathematics education research as their career track.

The perspective of high-education programs

Looking at the identified duties and responsibilities from the perspective of high-education programs, it is evident that graduate studies serve as a natural platform for developing literacy in mathematics and mathematics education. Some of the mathematics education graduates gain experience teaching academic courses (usually as teaching assistants), publishing in peer-reviewed literature, and presenting at conferences (usually doctoral students). At the same time, graduate students in typical study programs rarely get the opportunity to mentor research students, seek external funding for research projects, participate in academic committees, and provide consulting research services. This gap between the insufficient preparation of prospective MERchers and their future duties is compatible with Hauk and Tsay's (2013) critique on the preparation of researchers in mathematics:

[The reader may need to know that] $80 \%$ of people who complete doctorates in mathematics will spend their career in a job where teaching responsibilities take up more of their time - and are expected to take more of their time - that their research. What they also [should] know is that most doctoral programs in mathematics departments prepare graduate students as if the opposite were true (as if more time and energy were going to be spent on research that on teaching) (p. 1-2).

The aforementioned "non-research" duties of MERchers require special competences and propensities, and therefore, the relevant decision makers and authorities may consider systematic and structured frameworks, such as workshops, courses, and training programs, to promote these skills among young professors and graduate students (Gordon, 2014). For instance, in this study we found that MERchers are expected to collaborate extensively with multiple colleague researchers, mathematics education practitioners and organizations. Thus, a special focus should be placed during training on cultural, linguistic, gender, and ethnic diversity in human communication. Promoting the whole set of competences that are relevant to MERcher practices is particularly important in the case of doctoral students since they are natural candidates for academic careers in mathematics education.

The perspective of graduate students who are considering mathematics education research as a career track The study findings suggest some practical advice for graduate mathematics education students who are considering an academic career. Overall, the findings support Feibelman's (2011) claim that "a PhD is not enough" for a successful scientific career. Specifically, for students completing doctoral studies, a PhD should be a means to an end of gaining extended knowledge and skills, rather than a goal in itself. Such knowledge and skills are prerequisites for applying for MERcher positions and are necessary for fulfilling future academic duties. Hence, students who are considering academic careers 
must be proactive during their studies (cf., Lee \& Rolley, 2014). For instance, acquiring extensive knowledge in research methodologies (and not only the ones used in studies in which the student was personally involved) can be helpful when teaching academic courses and mentoring research students; being well versed in research trends in fields that are affiliated with mathematics education (such as science education, psychology, learning sciences) can enhance collaboration with other researchers and participation in multidisciplinary research; networking with schools and teachers can facilitate the conducting of research. In addition, publications in peer-reviewed journals and conference presentations are among the main activities that attest to the candidate's possession of the skills required for a professor's position. Thus, while working on their PhD dissertations, aspiring professors should seek opportunities to publish and present their work.

\section{From the current study's findings towards further exploration of expertise in mathematics education research}

Selected findings from the current study indicate some of the current trends and norms in the mathematics education research community. In this section we use these findings to formulate questions and goals for further studies on expertise in mathematics education research:

The first finding is the diversity of requirements regarding the candidates' mathematical background: from "scholastic mathematics" to a master's and even doctoral degree in mathematics. Notably, in all the cases in which an advanced mathematical background was required, the applicants were expected to teach undergraduate and graduate courses in mathematics. Thus, it seems that education faculties associate the MERchers' mathematical backgrounds with their teaching duties. In light of this finding, it would be interesting to explore the role of mathematics knowledge in conducting research in mathematics education ${ }^{10}$. On the one hand, it is obvious that MERchers should be highly proficient in mathematics, the learning and teaching of which they investigate; on the other hand, by extrapolating the principle according to which there should be a difference of at least one academic degree between teachers and their students (e.g., Zazkis \& Zazkis, 2011), we encounter a paradoxical situation when only mathematical graduates can study the teaching and learning of university students and only mathematicians can explore mathematicians (see Liljedahl, 2004; Kontorovich \& Koichu, in press; Weber, 2008 for empirical contradictions of this principle). Consequently, it is interesting to understand whether the "mathematical ceiling" of a researcher automatically predetermines (or limits) the potential research population and her or his research interests. Similar questions can be asked about the role of pedagogical and methodological knowledge in education research. We believe that these questions should be explored in the framework of studies aimed at revealing the components of MERchers' knowledge bases.

The second finding is the spectrum of MERchers' duties identified, whereby education faculties consider research, publishing, and pursuing external funding top priority. Indeed, all of the announcements referred to these duties in an explicit and result-oriented manner: 'A candidate should supply a record of scholarly research and potential to secure external funding', 'Preference will be given to candidates who have successful grant writing experience', 'The ideal candidate will be an accomplished researcher, with a record of funded research activities and scholarly publications'. The priority given to these duties is particularly prominent when contrasted with the formulations used to describe MERchers' other duties: 'The faculty member who fills this position also may contribute to the School coursework', 'Preferred qualification for both positions include teaching experience in K-12 schools', 'The accepted candidates are expected to contribute to the national visibility, stature, and impact of XX [name of the university] mathematics education program' (italics added). In light of the above, it is interesting to explore how MERchers themselves perceive their professional identity: Do they experience tension between its components, and if so, how do they cope with it?

The third finding is that only $49 \%$ of position announcements were aimed at MERchers with research interests in particular sub-areas of mathematics education, and two thirds of those referred to the said

\footnotetext{
${ }^{10}$ In teacher education, the relations between mathematical knowledge and pedagogical knowledge are explored and discussed extensively (e.g., Jaworski, Wood \& Dawson, 1999; Zazkis \& Zazkis, 2011).
} 
interests as being preferable but not mandatory. On the one hand, this openness and flexibility is mutually beneficial for the education faculties and the MERchers: Education faculties can employ researchers in different areas, making the faculties multi-faceted, more visible, and more significant in the field. The MERchers, in turn, appear to be more independent in their research. On the other hand, and in light of the second finding, this openness makes MERchers more dependent on financial organizations and journal editorial boards. Consequently, we recommend investigating what attributes determine the research scope and interests of the MERchers and what considerations are involved when MERchers initiate a particular study?

\section{Acknowledgements}

We would like to thank Irina Kontorovich for her assistance in organizing the data corpus.

\section{References}

Abu-Zaid, A., \& Alkattan, K. (2013). Integration of scientific research training into undergraduate medical education: A reminder call. Medical Education Online, 18.

Alon, U. (2009). How to choose a good scientific problem. Molecular Cell, 35, 1.

Alon, U. (2010). How to build a motivated research group. Molecular Cell, 37, 151-152.

Carlson, M., \& Bloom, I. (2005). The cyclic nature of problem solving: An emergent multidimensional problem-solving framework. Educational Studies in Mathematics, 58, 45-75.

Chamovitz, D. A. (2010). Lab family feud. Science, 330, 1177.

Chen, X., \& Anderson, C. (2008). Reflections on becoming a successful researcher. Educational Psychology Review, 20(1), 65-70.

Clarke, M. (2004). Reconceptualising mentoring: Reflections by an early career researcher. Issues in Educational Research, 14(2), 121-143.

Day, A. (1996). How to get research published in journals. Aldershot, UK: Gower Press.

Delamont, S., Atkinson, P., \& Parry, O. (2004). Supervising the PhD: A guide to success. Maidenhead, UK: SRHE and Open University press.

Elo, S., \& Kyngas, H. (2008). The qualitative content analysis process. Journal of Advance Nursing, 62(1), 107-115.

Feibelman, P. J. (2011). A PhD is Not Enough: A Guide to Survival in Science. Basic Books.

Gordon, W. (2014). Developing scientists' "soft" skills. Eos, 95(6), 55-56.

Gordon, T. P., \& Porter, J. C. (2009). Reading and understanding academic research in accounting: A guide for students. Global Perspective on Accounting Education, 6, 25-45.

Grammatikopoulos, V., Gregoriadis, A., \& Zachopoulou, E. (2013). Evaluating an early childhood educators' training in six European countries. The International Journal of Innovation and Quality in Learning, 2, 15-21.

Hanus, P. H. (1897). The preparation of the high school teacher of mathematics. The School Review, 5, 504-518.

Haser, Ç, \& Çakiroğlu, E. (2012). Conceptions of research and being a researcher among mathematics education doctoral students. In M. S. Hannula, P. Portaankorva-Koivistro, A. Laine, \& L. Naveri (Eds.), Current State of Research on Mathematical Beliefs XVIII: Proceedings of the 18 th MAVI (Mathematical Views) Conference (pp.163-174). Finnish Research Association for Subject Didactics: Helsinki, Finland.

Hauk, S., \& Tsay, J.-J. (2013). Using cases: Experts talk about their experiences. In S. Hauk, N.M. Kung, J.-J. Tsay, \& E. Hsu (Eds), Video Cases for college mathematics instructor professional development. Retrieved on February 11th, 2014 from http://collegemathvideocases.org/pdf/UsingCases.pdf.

ICTP (2004). One Hundred Reasons to be a Scientist. ICTP Publications \& Printing Section: Trieste.

Jaworsky, B., Wood, T., \& Dawson, S. (1999). Mathematics Teacher Education: Critical International Perspectives. Falmer Press.

Kontorovich, I. \& Koichu, B. (in press). A case study of an expert problem poser for mathematics competition. International Journal of Science and Mathematics Education.

Lee, G. A., \& Rolley, J. X. (2014). Early-career researchers: what's in it for us? Journal of Advanced Nursing. Retrieved on 3 February, 2014 from http:/ /onlinelibrary.wiley.com/doi/10.1111/jan.12225/pdf.

Liljedahl, P. (2004). The AHA! Experience: Mathematical contexts, pedagogical implications. Unpublished Ph.D thesis. Burnaby: Simon Fraser University.

Ma, X. (2001). Participation in advance mathematics: Do expectation and influence of students, peers, teachers, and parents matter? Contemporary Education Psychology, 26(1), 132-146.

Man, J. P., Weinkauf, J. G., Tsang, M., \& Sin, D. D. (2004). Why do some countries publish more than others? An international comparison of research fundings, English proficiency and publication output in highly ranked general medical journals. European Journal of Epidemiology, 19(8), 811-817.

Newell, A., \& Simon, H. A. (1972). Human Problem Solving. Englewood Cliffs, NJ: Prentice-Hall.

Nurius, P. S., \& Kemp, S. P. (2013). Transdisciplinarity and Translation: Preparing Social Work Doctoral Students for High Impact Research. Research on Social Work Practice. Published online before print. Retrieved from http://rsw.sagepub.com/content/early/2013/11/15/1049731513512375.full.pdf+html.

Pavan, A. (2013). A new perspective on the quest for education: The Saudi Arabian way to knowledge society. Higher Educational Studies, 3(6), 25-34.

Riley, K., \& Torrance, H. (2003). Big change question As national policy-makers seek to find solutions to national education issues, do international comparisons such as TIMMS and PISA create a wider understanding, or do they serve to promote the orthodoxies of international agencies? Journal of Educational Change, 4(4), 419-425.

Safford, T. H. (1893). Instruction in mathematics in the United States. Bulletin of the New York Mathematical Society, 3, 4-8. 
Sales, N. (2013). Flipping the classroom: Revolutionising legal research training. Legal Information Management, 13(4), 231-235.

Schoenfeld, A. (1992). Learning to think mathematically: problem solving, metacognition, and sense making in mathematics. In D. A. Grows (Ed.), Handbook of research on mathematics teaching and learning (pp. 334-370). New York: Macmillan.

Sneider, R., \& Larner, K. (2009). The Art of Being a Scientist: A Guide for Graduate Students and their Mentors. Cambridge University Press.

Spronken-Smith, R., Mirosa, R., \& Darrou, M. (2013). 'Learning is an endless journey for anyone': Undergraduate awareness, experiences and perceptions of the research culture in a research-intensive university. Higher Educational Research $\mathcal{E}$ Development.

Strnadova, I., Cumming, T. M., Knox, M., \& Parmenter, T. (2013). Building an inclusive research team: The importance of team building and skill training. Journal of Applied Research in Intellectual Disabilities, 1-10.

Townsend, P. (2004). Reflections on becoming a researcher: Peter Townsend interviewed by Paul Thompson. International Journal of Social Research Methodology, 7(1), 85-95.

Ullrich, L. E., Dumanis, S. B., Evans, T. M., Jeannotte, A. M., Gale, K., Wolfe, B. B., \& Forcelli, P. A. (accepted). Educational Psychology.

Van Someren, M. Y., Barnard, Y. F., \& Sandberg, J. A. C. (1994). The think aloud method: A practical guide to modeling cognitive processes. London: Academic Press.

Ward, A. (2013). How well are we meeting the educational expectations of EIE students? Proceedings of the IETEC'13 Conference. Retrieved on $\quad$ November $21 \quad$ from http://www.ietecconference.com/ietec13/conferenceproceedings2013/papers/Wendesday/WP2/WP2.1_submission_53.pdf. Ho Chi Minh City: Vietnam.

Weber, K. (2008). How mathematicians determine if an argument is a valid proof. Journal for Research in Mathematics Education, $39,431-459$.

Zaslavsky, O., \&Leikin, R. (2004). Professional development of mathematics teachers educators: Growth through practice. Journal of Mathematics Teachers Education, 7(1), 5-32.

Zazkis, R., \& Zazkis, D. (2011). The significance of mathematical knowledge in teaching elementary methods courses: perspectives of mathematics teacher educators. Educational Studies in Mathematics, 76(3), 247-263. 